Marquette University

e-Publications@Marquette

Theology Faculty Research and Publications

Theology, Department of

$11-1-2018$

\title{
A Soldier's Faith: The Civil War Experiences and Reflections of William Porcher DuBose
}

Robert B. Slocum

Marquette University

Accepted version. Journal of Anglican Studies, Vol. 16, No. 2 (November 2018): 170-187. DOI. (C) 2018 Cambridge University Press. Used with permission. 
Marquette University

e-Publications@Marquette

\title{
Theology Faculty Research and Publications/College of Arts and Sciences
}

This paper is NOT THE PUBLISHED VERSION; but the author's final, peer-reviewed manuscript. The published version may be accessed by following the link in th citation below.

Journal of Anglican Studies, Vol. 16, No. 2 (November 2018): 170-187. DOI. This article is (C) Cambridge University Press and permission has been granted for this version to appear in $\underline{\mathrm{e}}-$ Publications@Marquette. Cambridge University Press does not grant permission for this article to be further copied/distributed or hosted elsewhere without the express permission from Cambridge University Press.

\section{A Soldier's Faith: The Civil War Experiences and Reflections of William Porcher DuBose}

\author{
Robert B. Slocum
}

\begin{abstract}
The noted Episcopal theologian William Porcher DuBose was a seminarian when the American Civil War began. He was torn between continuing his studies for ordination and joining the Confederate Army. He felt duty bound to defend his homeland, and he served heroically, wounded in combat, and taken as a prisoner of war. Troubled by the senselessness and inhumanity of war, he was eventually ordained and served as a military chaplain. He devoted himself to faith and ministry when he realized his country and culture were lost. DuBose vividly presents his views on war and faith in his wartime correspondence with his fiancée and later wife Anne Barnwell Perroneau, and other writings. His experiences of loss and poverty were the basis for his theology of the cross and his understanding of the role of suffering in the Christian life, and he subsequently dedicated himself to faith, peace, and reconciliation.
\end{abstract}

Keywords: American Civil War; Confederate States of America; William Porcher DuBose; Episcopal Church; military chaplains; Anne Barnwell Perroneau; soteriology; suffering; theology of the cross 


\section{Introduction: Theological Contributions of DuBose}

William Porcher DuBose (April 11, 1836-August 18,1918) is widely considered to be the most creative and original theologian in the history of the Episcopal Church.[ 1] He published seven books of theology, and he was a frequent contributor to The Constructive Quarterly, an ecumenical journal.[ 2] DuBose's theology was drawn from the lessons of his personal experience. He always spoke 'from himself'. [ 3] He presented this synthesis of life experience and reflection in his autobiographical Turning Points in my Life (1912), in which he recalled his experiences of conversion, loss, and discovery. His soteriology (theology of salvation), the heart of his theology, emphasizes human participation in the life/death/resurrection of Christ so that his salvation is realized in us.[ 4] DuBose reflected on the role of the Holy Spirit as the active principle of unity, community, and Christ's saving presence in the life of the church.[ $\underline{5}$ ] He upheld the continuity of church tradition but looked to rediscover the truth of faith in each new context and situation.[ 6 ]

DuBose's systematic approach to the process of salvation was first presented in The Soteriology of the New Testament (1892). He applied his theological understanding to early church history in The Ecumenical Councils (1896). He believed in working out extremes through open discussion in the church, allowing different perspectives to correct and complement each other. At a reunion of his former students after 36 years of teaching at the University of the South in Sewanee, Tennessee, DuBose noted that 'the gathering is made up, not of those of one way, but of those of all the ways of thinking and believing in the Church'.[ 7] He sought to present the 'epexegesis', the 'postulates or presuppositions' of biblical authors in scriptures. [ 8] He applied his theological method to the synoptic gospels in The Gospel in the Gospels (1906), the Pauline writings in The Gospel According to Saint Paul (1907), the Letter to the Hebrews in High Priesthood and Sacrifice (1908), and the Johannine writings in The Reason of Life (1911).

DuBose served at Sewanee as chaplain of the University of the South from 1871 to 1883 . He helped to establish the School of Theology at Sewanee and taught in both the College of Arts \& Sciences and the School of Theology, and served as dean of the School of Theology from 1894 to 1901. His life is commemorated as a 'lesser feast' of the Episcopal Calendar.[ $\underline{9}$ ]

W.H. Moberly described DuBose in 1908 as 'one of the foremost philosophical theologians of our time';[10] and in 1972 Sidney Ahlstrom stated DuBose was 'one of the most profound American theologians' of his period.[11] William Sanday, Lady Margaret Professor of Divinity at Oxford, likewise stated 'America should make much of Dr. DuBose. I strongly suspect that in his own proper field - which I might perhaps describe as the Philosophy of the Christian Religion - he is the wisest writer on the other side of the Atlantic; indeed it may not be too much to say, the wisest Anglican writer ... on both sides of the Atlantic.'[12]

\section{Patriotism, Ordination, and Ambivalence}

DuBose was in his second year of preparing for ordained ministry when the American Civil War began with the Confederate shelling and seizure of Fort Sumter in the harbor of Charleston, South Carolina, on 12 April, 1861.[13] This brought into sharp focus the conflict for DuBose between military service and Christian ministry. Prior to the Civil War he attended the South Carolina Military College, The Citadel, in Charleston, South Carolina, as an undergraduate. He was a very successful cadet at The Citadel. He served as the ranking officer in his class, and as an assistant professor in the English department. He graduated from The Citadel with first class honors in December 1855. After earning the Master of Arts degree at the University of Virginia in 1859 with studies in Latin, Greek, French, and moral science, he entered the diocesan seminary in Camden, South Carolina, in October 1859.

DuBose struggled with the decision whether to continue his preparation for ordained ministry or join the Confederate military to fight in the Civil War. On November 4, 1861, he wrote his fiancée (and later wife) Anne Barnwell Peronneau ('Nannie') from Camden to explain his conflict:

I have strong views on the subject of a minister's, or even one in my situation, entering military service ... Besides the necessity which it involves of neglecting the service of God for one which however 
important \& urgent, cannot possibly be more so than the work of the ministry, I go so far as to believe that one who has devoted his life to God can no longer call it his own, \& therefore has no right to give it away, or even to endanger it in any other cause whatever, even though it be so sacred a one as that of Country. Of course the emergency may become such as to break down all scruples, \& render it necessary, and therefore right, for even these to take up arms; \& in that case I do not think I w'd be behind others in offering myself - but I trust that it will be a real necessity only that tempts me from my steadfast pursuit of God's service in the ministry to which He has called me.[14]

In the same letter DuBose emphatically states his preference for his future: 'Oh, that we could have peace, \& could go quietly and uninterruptedly about our regular occupations \& duties!'[15] A week later DuBose told Nannie that he 'w'd remain quietly in the seminary' if he 'were as most of the other students here' since 'many more men will be sure to offer their service than can possibly be armed, \& therefore of any use'. But he acknowledged that he had special training and services to offer the military: 'If any new regiments or companies are organized, drill masters will be needed, particularly now that the cadets are in active service. In that case I shall feel called upon to offer my services.'[16]

There was also pressure on DuBose to leave the seminary and join the military. Nannie states to him on November 10, 1861: 'As to your natural inclination to come and fight for the safety of Carolina I cannot imagine that anyone who knows you will doubt ... But you have dedicated yourself soul and body to the service of God in another way, and no one has the smallest right to interfere with your private judgment of which is the right moment to yield to the pressure from without.'[17] Nannie certainly respects his Christian vocation to ordained ministry, and upholds his autonomy and free decision-making in the face of outside pressure. But she does seem to expect DuBose will enter the military, and his decision is essentially a question of when instead of if he will 'yield to the pressure from without'. Her letter also provides insight into the motivation that would ultimately overcome DuBose's reluctance to leave seminary for the military: 'to fight for the safety of Carolina' as his homeland faced war and invasion.

DuBose entered the military on November 21, 1861, as the adjutant of the Holcombe Legion.[18] He states the Holcombe Legion was organized by the Governor of South Carolina as 'a command of State troops for State defense', and its 'organization was committed to the officers of the State military academy, the Citadel'. DuBose states his appointment as adjutant 'necessitated' his immediate departure from the seminary to participate in 'the organization and discipline of the legion'.[19]

DuBose also recalls he received an important letter from his father who took 'a very ardent interest' in support of the war, but who also respected DuBose's independence and autonomy in making his own decisions. DuBose believes his father's letter 'was intended to commend my act in following my own judgment rather than his wishes in this particular matter. But he soon manifested his relief and pleasure at my somewhat belated patriotism. He sent me down a set of military trappings for my horse which was rather exceptional in its quality and style.'[20]

But DuBose's quandary and ambivalence concerning military service was not resolved when he joined the Holcombe Legion. DuBose writes to Nannie on July 13, 1862, and tells her about the death of a soldier in battle, and that 'the very place where he has been buried will remain unknown'. He then laments: 'Such is war! Oh for a perpetual end of it! I do not like to realize the fact that I am engaged in a profession whose avowed object is to destroy my fellow man, \& create widows \& orphans throughout the land. I feel no desire to be in a battle, and would be perfectly satisfied for peace to come before I win my laurels.'[21] He also told Nannie on March 9, 1863, 'you need not imagine that we are, any of us, anxious for [stirring] service, or that it is a disappointment to [be] kept out of it. We take when it comes, and are not sorry when it does not come.'[22]

DuBose again expressed his distaste for war in a letter to Nannie from Jackson, Mississippi, on July 10, 1863. He describes a prayerful interlude in a peaceful place: 'We are in a beautiful lawn with forest trees for shade, and this morning the birds were singing and everything looked as peaceful as though there were no such thing as war.' He adds that on this beautiful day 'it so happened too that I read for the morning the Collect \& Epistle [prayer and scripture] for the 5th Sunday after 
Trinity'. However, DuBose was keenly aware of the dissonance between the meaning of his prayers and the war. He states the spirit of the prayer and Scripture he read 'is so exactly the reverse of that of war, that I could not but shudder more than ever at the systematic \& deliberate way men go about murdering each other. When will this thing end, and [sacred] peace be restored to us!'[23]

On March 1, 1863, DuBose tells Nannie he seeks to avoid 'two dangers' as he wrestles with his direction concerning military service or ordained ministry. One danger is 'the temptation to mistake personal \& earthly motives for the dictates of conscience \& duty, [\&] to construe an increasing distaste for the service \& a natural longing for a more congenial occupation (to say nothing of less worthy motives) into a sense of duty leading me to exchange the one for the other'. But he also seeks to avoid 'the danger of remaining indefinitely in the service simply from neglect to institute a comparison between the contending claims of the service \& the ministry, or from a depreciation of the spiritual in comparison with the temporal claims upon me'.[24] After overlooking Nannie's birthday on March 2, DuBose writes her on March 4 and emphatically states his frustration with his military service: 'The years are slipping by very rapidly, and I long to be released from the painful necessity which this unnatural war imposes upon us, of spending so much precious time in an occupation which seems to us so senseless and inhuman.'[25]

DuBose was aware of efforts being made on his behalf to let him be ordained and serve as a chaplain. DuBose expressed his mixed feelings to Nannie. On June 11, 1863, he promises to write his bishop:

today or tomorrow, when I have given it a little more consideration, and will also write to you more fully in my next, or else send my letter to him, as you request. If the thing can be effected, I do not know that I can refuse. I would a thousand times rather be engaged in the work of the ministry than in my present occupation, but I shrink from such a position in proposition as I know its difficulties \& my capacity \& qualifications for it.[26]

On August 15, 1863, DuBose wonders 'what progress the B'p [bishop] has made'. He admits that in light of recent military disasters he 'was on the point of writing to him to request him to drop the matter for a time at least, if not finally'. But he resolves 'to let matters take their course'. He admits 'I am still doubtful however about the propriety of leaving the service at such a critical time and therefore cannot feel anxious to see him succeed too soon. I trust that Providence will decide for me in the best way.'[27]

DuBose was allowed to make the transition from combatant to chaplain at the end of 1863 . He resigned his commission as adjutant on November 1, 1863, and he was ordained deacon on December 13, 1863, in Camden, South Carolina. The Confederate government commissioned him to serve as a chaplain in Brigadier General Joseph B. Kershaw's brigade. DuBose states his commission in Kershaw's brigade was 'secured by General Kershaw himself and Bishop Davis, without my knowledge or consent. I had been very near ordination at the beginning of the war and I suppose my friends thought that I had had my share of hard service.'[28] DuBose moved from serving as an adjutant and combatant to serving as a chaplain, but he continued to serve in the Confederate army until the end of the war, and held the rank of captain.[29] He found a way to serve in the Civil War as an ordained minister and to serve the military of his country.

\section{Experiences of Loss and Suffering}

DuBose was a courageous soldier who was wounded three times in battle during the Civil War. He was struck by shrapnel in the knee on August 23, 1862, at the battle of Rappahannock Station, Virginia.[30]

On August 30, 1862, at the Second Battle of Manassas, he participated in an advance on the enemy in which his brigade was quickly 'decimated', and two thirds of the men were killed or wounded. The Confederates were victorious elsewhere on the line of battle, and the enemy began to retreat. DuBose stopped to pick up a flag on the ground, and the retreating enemy near DuBose soon realized 'only a few individuals' were following them. The enemy soldiers returned fire. 
Unfortunately, DuBose recalls, 'it so happened that I was the only one visible to them at that moment, standing with the flag in my hands. I had the pleasure of seeing rifles deliberately aimed at me.' At first he jumped down, but then he stood up to run, and 'at that moment a Minié ball hit me, tearing my clothes and the flesh off my back and just scraping my backbone. The enemy resumed their retreat and I was left standing there - paralyzed.' He was later able to leave the field of battle, but 'it was an awful experience' for him.[31] About a hundred men survived from the Holcombe Legion, and DuBose was commanded to reorganize them. DuBose was the unit's senior officer available for duty, and he organized the survivors of the Holcombe Legion into three companies.[32]

DuBose subsequently participated in the Confederate invasion of Maryland. On September 14, 1862, his brigade arrived at Boonesboro Gap. At Turner's Gap they fought in the Battle of South Mountain. After retreating at the end of the day, DuBose was ordered to return to the scene of the day's battle to see if the enemy had withdrawn from the field. He went on this reconnaissance with a party of soldiers, but he ultimately proceeded alone in the dark on the mountain. DuBose recalls 'When I got to the top, the silence of the night was so profound, that I thought it impossible there could be a body of men in the small space of the plateau, which I was to reconnoitre. Moving on quietly toward the edge, or cliff, behind which we had fought, I convinced myself more and more that there could be nothing there besides the primaeval and natural environment.'[33]

DuBose saw 'one or two figures not more than twenty steps in front of me', but he 'could not distinguish the uniform'. The figures proved to be enemy soldiers, and DuBose was taken prisoner when he was recognized as an adversary. Both DuBose and his 'immediate antagonist' were armed, and DuBose's weapon fired prematurely, but no one was seriously injured. Then 'the woods were alive'. DuBose tried to escape, and 'in the scuffle that ensued, I several times nearly did so, but my antagonist was a much larger and stronger man than I was, and I finally had to surrender to numbers'. [34]

Many years after the war DuBose was reunited with the soldier who captured him, and DuBose heard the other side of the story of that eventful night from Cronin, his captor. DuBose explains in Turning Points that 'friends of a faithful and deserving old soldier from Pennsylvania made my capture the ground for an application for pension, and I was requested to further his claim'. DuBose gave Cronin his testimony, and he did receive his pension. After that time DuBose 'occasionally received letters from Cronin expressing the desire to meet me again, and saying that he could not die happy without doing so'.[35]

DuBose's second reunion with Cronin was at Sewanee, Tennessee, 'thirty-five years at least after our first meeting'. DuBose was surprised when Cronin 'suddenly appeared there, ill and travel-worn, having made the journey across several States to see me again before he died'. They recalled the night of DuBose's capture. Cronin 'said I had come near killing him, and he had come nearer killing me; for when I had twice almost got away, he had at last, being of twice my strength, got me down, and then, with my own pistol, was in the act of shooting, when some mysterious force had held his hand and prevented him'. DuBose had a closer escape than he realized. He states Cronin 'made me sit down and write for him an account of our two encounters in war and in peace, and then as mysteriously made his disappearance'.[36] DuBose and Cronin were enemies in war, but they formed a bond and were reconciled in peace.

After his capture at Boonesboro Gap, DuBose was incarcerated as a prisoner of war at Fort Delaware until he was returned in an exchange of prisoners.[37] During his imprisonment he was infested with lice. He recalls 'I had not as yet a change of underclothing and to my horror on the third or fourth day, I found myself inhabited in spite of everything I could do to prevent it'.[38] This was very difficult for him. He recalls 'I have to confess that the strongest religious principles I could summon to my help were inadequate to this occasion.'[39]

On June 11, 1863, DuBose wrote Nannie to say: 
I remember that when I was taken prisoner, I succeeded tolerably well in bearing with Xtian [Christian] patience the fatigue, exposure, hunger, thirst, heat, dust, dirt, confinement \& even the pain of separation from you \& home, until one day in Ft. Delaware I found on me a body insect, the first I had ever seen. I believe I could more easily have prepared myself to be shot for one of Pope's officers, than have reconciled myself cheerfully to this last affliction. It was the straw that broke the camel's back.[40]

After an exchange of prisoners freed him from Fort Delaware, DuBose arrived in Richmond on October 7, 1862. He soon assured Nannie that 'exposure \& hardship have done me much more good than harm, and I have seen a good deal of both. They are monsters that lose much of their hideousness on close inspection.'[41]

DuBose was wounded for the third time on December 13, 1862, while commanding the Holcombe Legion at Kinston, North Carolina, near Goldsboro. The legion was to defend a bridge just below Kinston. They were surprised by an attack in the early morning, and the soldiers were on the verge of panic. The situation worsened when DuBose was ordered to fall back and take up a position fifty yards behind their line. After that 'awful blunder', he recalls, 'a panic practically began, and I have never in my life had to work harder ... than in taking up that new position and bringing the men up to the point of meeting the enemy'.[42]

DuBose helped the soldiers to be 'as cool in possession of themselves as possible', but he was hit in the side by a Minié ball as he walked up and down the lines to encourage his command. He recalls 'fortunately the ball had scraped a part of itself off on the slope just in front of us and then passed through a half-a-dozen thick folds of clothing. As it was, it touched at least two mortal spots without actually penetrating. I had no feeling as I was suddenly hurried away in a stretcher to the rear.' DuBose was treated by surgeons who removed the Minié ball, leaving him 'painfully but no longer dangerously wounded'.[43] He admits to Nannie he 'received what I at first thought a mortal wound'. But the musket ball was extracted after he was carried 'three or four miles in a litter'.[44]

In addition to his own wartime hardships, wounds, and near brushes with death, DuBose shared and witnessed a variety of hard losses and painful situations with family and friends during and after the Civil War. DuBose writes to Nannie from Mississippi on July 5, 1863, during a retreat after the Confederate surrender of Vicksburg: 'This has been the severest day upon troops that I have known since entering the service. The heat has been intense, the dust most oppressive $\&$ the men have been almost literally without water.' He states 'I have seen men use water today which a horse w'd not touch ordinarily, stagnant, muddy \& hot. But I have no time for details this evening. You can imagine the depressing effect of the sudden \& unexpected blow upon us.'[45]

DuBose experienced a moment of shock and realization after the Confederate defeat at the battle of Cedar Creek on October 19, 1864, in the Shenandoah Valley of Virginia. He recalls in his 'Reminiscences' that 'Kershaw's brigade, which had never slept behind a field of battle, but always on it or before it, slept that night fifteen miles behind one. To others besides myself I think that night's experience was the turning point of the war.' He exclaims: 'To me - that night! - I felt as if everything was gone!'[46]

DuBose also recalls the battle of Cedar Creek in Turning Points in my Life, his spiritual autobiography. At Cedar Creek 'a glorious victory of the morning was converted into a disgraceful rout in the afternoon'. He could not sleep when the brigade rested that night behind the field of battle. DuBose explains 'the end of the world was upon me as completely as upon the Romans when the barbarians had overrun them'. He had never before considered 'the possibility of final defeat for the Confederate cause', but 'that night it came over me like a shock of death that the Confederacy was beginning to break'.[47] This proved to be a spiritual 'turning point' and occasion for renewed faith.

DuBose describes his realization that the Confederate cause was lost: 'the actual issue was all upon me that fateful night in which, under the stars, alone upon the planet, without home or country or any earthly interest or object before me, my very world at an end, I redevoted myself wholly and only to God, and to the work and life of His Kingdom, whatever and 
wherever that might be.' This was for DuBose an experience that 'can never be altogether lost, and I go back to it at times for such a sense of the utter extinction of the world, and presence of only the Eternal and the Abiding, as is seldom vouchsafed to one'.[48]

Gardiner Shattuck notes that DuBose believed his wartime experience 'forced him to realize for the first time how only divine, eternal truths were secure amid the misfortunes of life. With the collapse of the Confederacy and the subsequent decline of Southern civilization, the church remained the single institution capable of maintaining the ideals for which the South once had stood.'[49] DuBose explains to Nannie on October 31, 1864, 'since that unfortunate reverse of the 19th [the battle of Cedar Creek] I have been laboring harder to make my life \& ministry what they ought to be'.[50] His recognition of the approaching defeat of the Confederacy was an occasion of personal rededication to God and God's purposes. But it was deeply rooted in his very painful sense of loss at that time.

DuBose witnessed and shared many other severe losses during and after the Civil War. His parents died during the war. His father died in 1862 from measles he caught from soldiers when he ministered to them on a train. His mother died later the same year.[51] There was considerable suffering among DuBose's friends as well. Mrs. Haskell, a close family friend, heard in a single day of the death of her brother and two sons. Both sons had been DuBose's roommates in school - Charles Haskell at The Citadel, and William Haskell at the University of Virginia. DuBose named his first son William Haskell DuBose after his friend and Virginia roommate.[52] DuBose's home church, St. John's in Winnsboro, South Carolina, was severely damaged in Union General William T. Sherman's raid. According to one account, the church was 'wantonly burned', and its organ, furniture, books, and church bell were destroyed.[53]

General Robert E. Lee surrendered the Confederate Army of Northern Virginia on April 9, 1865, at Appomattox Court House, Virginia. DuBose encountered great desolation when he returned home after the war. His family home had 'lain in the centre of Sherman's famous march'.[54] DuBose recalls 'widows and bereaved persons were at every turn, and worst of all, facing us everywhere was the loss of our country'.[55] DuBose was deeply shaken by the loss of his homeland and country, his world, including the death of many loved ones and friends. He does not lament the end of slavery in his autobiography or published wartime correspondence.[56]

Sherman's march 'swept the country clean of every facility for private travel, animals or vehicles, as well as provisions and everything else'.[57] DuBose found 'the country was stript of the barest means of subsistence; our social and political condition was unendurable and hopeless'. DuBose's family was wealthy before the war, but 'utterly impoverished' after the war ended.[58] The 'carpet bag regime was at its height and its worst'. This was a time of lawlessness, fear, and exploitation by those in power. 'Barns and sometimes homes were burned by night.' DuBose's own home, the church rectory, was entered at night by a robber. The intruder was discovered in the bedroom where DuBose's daughter Susie and other relatives were sleeping.[59] South Carolina was a dangerous place after the Civil War, and DuBose knew many losses there.

DuBose was elected Chaplain and Professor of Moral Science at the University of the South in 1871. His wife and three children joined him at Sewanee in the early summer of that year. DuBose faced other great losses at Sewanee. His fourth child, Samuel, was born in the fall of 1871. Nannie's health began to fail at that time. She died in the following April. DuBose believed she 'never did recover from certain hardships endured during the war, for she was so utterly unselfish, and thoughtful of all except herself, that she impaired her health'. Samuel died in the spring of 1874, after lingering for some time following a severe bronchial attack. The intense pain of Samuel's death was still present many years later when DuBose dictated his 'reminiscences' for his son Haskell. DuBose recalls 'I used to carry him in my arms and he loved it. He died. I miss that little boy to this day. I miss him now.'[60]

\section{Poverty and Loss, Faith and Understanding}

DuBose learned, however, that experiences of loss provide occasion for human openness to God and dependence upon God. His experiences taught him the importance of poverty in the life of faith. He explains in Turning Points: 'The principle 
of prayer is rooted in the fact of need, want, poverty. Our Lord makes poverty the first condition of spiritual blessedness, because in it begins all that dependence upon God the end of which is oneness with Him. Out of that poverty come all godly sorrow, all noble meekness and humility, all hunger and thirst for rightness and fullness of life, all faith in God, all hope in self, all true self-realization and soul satisfaction.'[61] The emptiness of poverty can lead to openness of heart that is filled by the love of God. Experiences of loss and impoverishment can encourage dependence upon God, as DuBose turned more deeply to God when he was despairing in the war. DuBose certainly experienced 'need, want, poverty' during and after the Civil War. These experiences were formative for his faith and theology.

DuBose's experiences of loss were important for his understanding the role of the cross in the life of Jesus, and in the Christian life. He urges in his Transfiguration sermon at the 1911 reunion of his students at Sewanee:

the fact that even our Lord, in the needful and inevitable infirmity of our present humanity, had moments in which He needed to know anew that He was the Son of God, that He had to learn afresh upon the very cross that there is no such thing as a divine forsaking, though so often there seems to be, ought to teach us how to have faith in even our darkest hours, and hope when we are faintest and farthest off.[62]

Through his darkest hours and most painful losses DuBose came to experience there is no divine forsaking, even in the worst of times.[63]

DuBose's experiences of loss were also formative for his understanding of the role of suffering and the cross in Christian life, and Christology. He asks, rhetorically, in his Transfiguration sermon, 'For what is Jesus Christ but God in us and we in God? And what is the Cross but the actual process by which all that is not God dies in us, and all that is lives and grows in us?'[64]

DuBose knew the cross and its benefits through his experiences of loss in and after the Civil War. He describes and applies this connection of sacrifice and devotion in letters to Nannie during the war. On November 23, 1862, he writes her from the Dismal Swamp near Kinston, North Carolina, to say 'when we are lifeless \& cannot lift up our souls to God, it is always of advantage to us to turn to the man Jesus \& contemplate him under circumstances similar to our own, \& where can our experience extend where he did not reach.'[65]

DuBose writes Nannie on October 18, 1864, to tell her:

I do not know but that this separation so painful and trying has had the effect upon me of elevating \& spiritualizing my love, not only for you, but for my sisters \& others. Human affection seems to me a more sacred and holy thing than it used to, and while I believe I have acquired a larger capacity for loving myself, I learn to look with more interest upon the love of others ... the love of God strengthens \& sanctifies every other kind of love.[66]

The impact of DuBose's experiences of suffering and loss during the war can be seen in his later published theology. DuBose states in The Ecumenical Councils in 1896 that 'it is the cross that raiseth us; the pain of the world is the lever by which God lifts us to himself'. [67] The pain of the cross and the joy of God's presence can be known personally in the darkest times, as DuBose experienced in the war and afterwards. He explains in The Gospel in the Gospels in 1906 that God loves us and 'shares and endures with us and in us, all the extremest conditions and experiences of human life and destiny'.[68] DuBose came to know the love of God more deeply through his wartime experiences of separation, loss and suffering.

DuBose's aversion to war continued in later years. In 1911, some 50 years after the outbreak of the Civil War, he noted with approval the general 'raising of the question of arbitration and peace', and movement in the direction of 'the abolition of war'. He perceived 'an era of reconciliation and cooperation', He looked for 'at least the diminution and amelioration if not 
the actual extinction of war'.[69] Although the following years did not bring peace, DuBose's statement reflects the transformed life of a former cadet and soldier who lived for reconciliation and peace.

\section{Footnotes}

1 See Pittenger W. Norman, 'The Significance of DuBose's Theology', in William Porcher DuBose, Unity in the Faith (ed. W. Norman Pittenger; Greenwich, CT: Seabury Press, 1957), p. 21.

2 DuBose's seven books of theology were The Soteriology of the New Testament (New York: Macmillan, 1892); The Ecumenical Councils, Vol. 3 of Ten Epochs of Church History (ed. John Fulton; New York: Christian Literature Company, 1896); The Gospel in the Gospels (New York: Longmans, Green \& Co., 1906); The Gospel According to Saint Paul (New York: Longmans, Green \& Co., 1907); High Priesthood and Sacrifice: An Exposition of the Epistle to the Hebrews (New York: Longmans, Green \& Co., 1908); The Reason of Life (New York: Longmans, Green \& Co., 1911); and Turning Points in my Life (New York: Longmans, Green \& Co., 1912). The 11 essays originally published by DuBose in The Constructive Quarterly: A Journal of the Faith, Work, and Thought of Christendom were published in Pittenger (ed.), Unity in the Faith. This volume also included DuBose's essay, 'Christian Defense', originally published in W.M. Groton (ed.), The Sunday School Teacher's Manual (Philadelphia: G.W. Jacobs, 1911). Two anthologies of DuBose's writings are Jon Alexander, OP (ed.), William Porcher DuBose, Selected Writings (Sources of American Spirituality; New York: Paulist Press, 1988); and Donald S. Armentrout (comp.), A DuBose Reader: Selections from the Writings of William Porcher DuBose (Sewanee, TN: University of the South Press, 1984).

$\underline{3}$ DuBose, Turning Points, p. 15.

4 See Boak Slocum Robert, The Theology of William Porcher DuBose: Life, Movement, and Being (Columbia, SC: University of South Carolina Press, 2000), p. 44.

$\underline{5}$ See Robert Boak Slocum, The Anglican Imagination: Portraits and Sketches of Modern Anglican Theologians (Farnham, Surrey, and Burlington, VT: Ashgate, 2015 ; repr. London and New York: Routledge, 2016), p. 15.

6 See Slocum Robert B., 'DuBose, William Porcher', in Patrick W. Carey and Joseph T. Lienhard (eds.), Biographical Dictionary of Christian Theologians (Westport, CT and London: Greenwood Press, 2000), p. 162.

7 DuBose, Turning Points, p. 8.

8 DuBose, The Reason of Life, 30. See Slocum, The Theology of William Porcher DuBose, pp. 1-6.

$\underline{9}$ 'DuBose, William Porcher (Apr. 11, 1836-Aug. 18, 1918)', in Don S. Armentrout and Robert Boak Slocum (eds.), An Episcopal Dictionary of the Church, A User-Friendly Reference for Episcopalians (New York: Church Publishing, 2000), p. 155.

Moberly W.H., 'The Theology of Dr. DuBose', Journal of Theological Studies9 (January, 1908), pp. 161-187 (161). Sidney Ahlstrom, A Religious History of the American People (New Haven, CT: Yale University Press, 1972), pp. 727-728.

William Sanday, The Life of Christ in Recent Research (New York: Oxford University Press, 1908), p. 281.

Unlike Presbyterians, Methodists, and Baptists, the Episcopal Church was not divided along sectional lines over slavery prior to the outbreak of the American Civil War. After the outbreak of war, Episcopal leaders in the south formed the Protestant Episcopal Church in the Confederate States of America, 'a denomination whose constitution, canon laws, prayer book, and organization almost exactly mirrored those of the church in the United States'. Hein David and Shattuck Gardiner H.Jr., The Episcopalians (New York: Church Publishing, 2004), pp. 76-78. After the war, Presiding Bishop John Henry Hopkins was conciliatory and encouraged the southern bishops to attend the 1865 General Convention. Henry C. Lay, Bishop of Arkansas, and Thomas Atkinson, Bishop of North Carolina, attended the General Convention and were well received. The dioceses of the Confederate Episcopal Church subsequently resumed their former status in the Episcopal Church after a General Council of the Confederate Episcopal Church later that year, thereby ending the Confederate Episcopal Church. Hein and Shattuck, The Episcopalians, pp. 
79-80. See Thayer Addison James, The Episcopal Church in the United States, 1789-1931 (New York: Charles Scribner's Sons, 1951), pp. 198-199.

William Porcher DuBose, 'Letter to Anne Barnwell Peronneau', November 4, 1861, Camden, South Carolina, in W. Eric Emerson and Karen Stokes (eds.), Faith, Valor, and Devotion: The Civil War Letters of William Porcher DuBose (Columbia, SC: University of South Carolina Press, 2010), pp. 17-18. DuBose's collected Civil War letters were written during the period October 1861-April 1865. The original letters are archived at the South Carolina Historical Society in Charleston, South Carolina. William Porcher DuBose and Anne Barnwell Peronneau were married on April 30, 1863. William Porcher DuBose, 'The Reminiscences of William Porcher DuBose, D.D., S.T.D', p. 120. Unpublished autobiographical reflections compiled by William Haskell DuBose, 1946. Manuscript available in the School of Theology Library, University of the South, Sewanee, Tennessee.

DuBose, 'Letter to Annie Barnwell Peronneau', November 4, 1861, in Faith, Valor, and Devotion, p. 18.

William Porcher DuBose, 'Letter to Anne Barnwell Peronneau', November 11, 1861, Camden, South Carolina, in Faith, Valor, and Devotion, p. 21.

Anne Barnwell Peronneau, 'Letter to William Porcher DuBose', November 10, 1861, Charleston, South Carolina, in Faith, Valor, and Devotion, pp. 19-20.

W. Eric Emerson and Karen Stokes, 'Introduction', in Emerson and Stokes, Faith, Valor and Devotion: pp. xiii-xxix (xvii). The Holcombe Legion was named in honor of Lucy Holcombe Pickens, wife of South Carolina Governor Francis Pickens.

DuBose, 'Reminiscences', p. 69.

DuBose, 'Reminiscences', pp. 69-70.

William Porcher DuBose, 'Letter to Anne Barnwell Perroneau', July 13, 1862, Camp Hope, in Faith, Valor, and Devotion, p. 74.

William Porcher DuBose, 'Letter to Anne Barnwell Perroneau', March 9, 1863, in Faith, Valor, and Devotion, p. 148.

William Porcher DuBose, 'Letter to Anne Barnwell Perroneau DuBose', July 11, 1863, Jackson, Mississippi, in Faith, Valor, and Devotion, p. 192.

William Porcher DuBose, 'Letter to Anne Barnwell Perroneau', March 1, 1863, Holcombe Legion, in Faith, Valor, and Devotion, p. 143.

William Porcher DuBose, 'Letter to Anne Barnwell Perroneau', March 4, 1863, Holcombe Legion, in Faith, Valor, and Devotion, p. 144.

William Porcher DuBose, 'Letter to Anne Barnwell Perroneau', June 11, 1863, Jackson, Mississippi, in Faith, Valor, and Devotion, p. 175.

William Porcher DuBose, 'Letter to Anne Barnwell Perroneau DuBose', August 15, 1863, Isle of Hope, in Faith, Valor, and Devotion, p. 206.

DuBose, 'Reminiscences', pp. 125-26.

See Emerson and Stokes, Faith, Valor, and Devotion, p. xxiii; Wilson Charles Reagan, Baptized in Blood: The Religion of the Lost Cause, 1865-1920 (Athens, GA: University of Georgia Press, 1980), p. 148 ; Chitty Arthur BenjaminJr., Reconstruction at Sewanee: The Founding of the University of the South and its First Administration, 1857-1872 (Sewanee, TN: University Press, 1954), p. 142 , n. 1; Slocum, The Theology of William Porcher DuBose, pp. 2-3.

DuBose, 'Reminiscences', p. 84; Emerson and Stokes, 'Introduction', in Faith, Valor, and Devotion, p. xix.

DuBose, 'Reminiscences', pp. 85-88; Emerson and Stokes, 'Introduction', in Faith, Valor, and Devotion, p. xix.

DuBose, 'Reminiscences', p. 89; Emerson and Stokes, 'Introduction', in Faith, Valor, and Devotion, pp. xix, xxvii, n. 22.

DuBose, 'Reminiscences', p. 95.

DuBose, 'Reminiscences', pp. 95-96; Emerson and Stokes, 'Introduction', in Faith, Valor, and Devotion, p. xx.

DuBose, Turning Points in my Life, p. 37. In 1911, the fortieth anniversary of DuBose's coming to Sewanee, there was a reunion of his former students at the University of the South on August 2-6. DuBose read 
autobiographical papers at the morning sessions of the reunion. These autobiographical papers and other materials were published as his Turning Points in my Life.

DuBose, Turning Points, pp. 37-38.

Fort Delaware was located near the canal that connects the Chesapeake Bay with Delaware Bay. DuBose, 'Reminiscences', p. 102. Fort Delaware is located on Pea Patch Island in the Delaware River.

DuBose, 'Reminiscences', pp. 102-103.

DuBose, 'Reminiscences', p. 103.

William Porcher DuBose, 'Letter to Anne Barnwell Perroneau DuBose', June 11, 1863, Jackson, Mississippi, in Faith, Valor, and Devotion, pp. 174-75.

William Porcher DuBose, 'Letter to Anne Barnwell Perroneau', October 9-10, 1862, Richmond, Virginia, in Faith, Valor, and Devotion, 103. On October 8 he wrote Nannie that he 'reached Richmond yesterday' (William Porcher DuBose, 'Letter to Anne Barnwell Perroneau', October 8, 1862, Richmond, Virginia, in Faith, Valor, and Devotion, p. 100). DuBose was officially exchanged on November 10, 1862 (Emerson and Stokes, 'Introduction', in Faith, Valor, and Devotion, p. xxi).

DuBose, 'Reminiscences', p. 117-18; Emerson and Stokes, 'Introduction', in Faith, Valor, and Devotion, pp. xxixxii.

DuBose, 'Reminiscences', pp. 118-19; Emerson and Stokes, 'Introduction', in Faith, Valor, and Devotion, p. xxii.

William Porcher DuBose, 'Letter to Anne Barnwell Perroneau', December 16, 1862, Hospital Goldsboro, in Faith, Valor, and Devotion, p. 120.

William Porcher DuBose, 'Letter to Anne Barnwell Perroneau DuBose', July 5, 1863, in Faith, Valor, and Devotion, p. 187.

DuBose, 'Reminiscences', pp. 133-34.

DuBose, Turning Points, pp. 48-49. See Slocum, The Theology of William Porcher DuBose, pp. 6-7; Emerson and Stokes, 'Introduction', in Faith, Valor, and Devotion, p. xxv.

DuBose, Turning Points, pp. 49-50.

Gardiner H. Shattuck, Jr., A Shield and Hiding Place: The Religious Life of the Civil War Armies (Macon, GA: Mercer University Press, 1987), p. 125.

William Porcher DuBose, 'Letter to Anne Barnwell Perroneau DuBose', October 31, 1864, New Market, in Faith, Valor, and Devotion, p. 321. Emerson and Stokes identify DuBose's reference of 'the 19th' with Cedar Creek in their 'Introduction' to Faith, Valor, and Devotion, pp. xxv, xxix n. 49.

DuBose, 'Reminiscences', p. 80.

DuBose, 'Reminiscences', pp. 149-50. William Haskell DuBose compiled his father's 'Reminiscences' after DuBose told him the stories.

Sidney Thomas Albert, A Historical Account of the Protestant Episcopal Church in South Carolina, 1820-1957, Being a Continuation of Dalcho's Account, 1670-1820 (Columbia, SC: R.L. Bryan Company, 1957), p. 625. See DuBose, 'Reminiscences', p. 141.

DuBose, Turning Points, p. 39.

DuBose, 'Reminiscences', p. 139.

See DuBose, Turning Points; Faith, Valor, and Devotion. DuBose did not attack or defend the institution of slavery in his writings. DuBose's family owned 204 slaves in 1860 (Emerson and Stokes, 'Introduction', in Faith, Valor, and Devotion, p. xv). DuBose considered the future of their family plantation in a letter to Nannie in 1864: 'There is not a better nor more devoted set of negroes in the state than ours. I would be glad if Farmington could be kept up, but I disapprove of owning negroes if you cannot live with them' (William Porcher DuBose, 'Letter to Annie Barnwell Perroneau DuBose', March 4, 1864, Greenville, in Faith, Valor, and Devotion, pp. 249-50). DuBose's body servant William went with him to the Civil War. DuBose frequently mentions him when he sends news home to Nannie in letters. On one occasion DuBose tells Nannie 'I have sent William home on a short furlough. He has served me faithfully \& cheerfully \& so far from applying for permission to go, seemed to dislike going without me' (William Porcher DuBose, 'Letter to Annie Barnwell Perroneau DuBose', September 19, 1863, Mt. Pleasant, in 
Faith, Valor, and Devotion, p. 216). William returned home with DuBose after the war (Emerson and Stokes, 'Epilogue', in Faith, Valor, and Devotion, p. 334).

DuBose, 'Reminiscences', p. 138.

DuBose, Turning Points, p. 51.

DuBose, 'Reminiscences', pp. 144-46.

DuBose, 'Reminiscences', pp. 153-54. See Slocum, The Theology of William Porcher DuBose, pp. 6-8.

DuBose, Turning Points, p. 87.

William Porcher DuBose, 'Transfiguration Sermon', in Turning Points, pp. 120-21. The sermon was preached by DuBose on the Feast of the Transfiguration, Sunday, August 6, 1911, the last day of the reunion, in the University Chapel, the University of the South, Sewanee, Tennessee.

See Slocum, The Theology of William Porcher DuBose, 8.

DuBose, 'Transfiguration Sermon', in Turning Points, p. 118.

William Porcher DuBose, 'Letter to Anne Barnwell Perroneau', November 23, 1862, Dismal Swamp, near Kinston, North Carolina, in Faith, Valor, and Devotion, p. 117.

William Porcher DuBose, 'Letter to Anne Barnwell Perroneau DuBose', October 18, 1864, Fisher's Hill, Virginia, in Faith, Valor, and Devotion, p. 319.

DuBose, The Ecumenical Councils, p. 85. See Slocum, The Theology of William Porcher DuBose, p. 64.

DuBose, The Gospel in the Gospels, p. 271. See Slocum, The Theology of William Porcher DuBose, p. 64.

DuBose, The Reason of Life, p. 1. See Slocum, The Theology of William Porcher DuBose, p. 103. 